\title{
New electrochemical sensors for detection of nitrites and nitrates
}

\section{Micaela Badea ${ }^{\mathrm{a}}$, Aziz Amine ${ }^{\mathrm{b}}$, Giuseppe Palleschi ${ }^{\mathrm{c}}$, Danila Moscone ${ }^{\mathrm{c}}$, Giulia Volpe ${ }^{\mathrm{c}}$, Antonella Curulli d,*}

a Biotechnology Department, Institute for Chemical Research, University of Bucharest, Bucharest, Romania

${ }^{\mathrm{b}}$ Facultè de Sciences et Techniques, Universitè Mohammadia, Mohammadia, Morocco

"Dipartimento di Scienze e Tecnologie Chimiche, Università di Roma "Tor Vergata", Rome, Italy

d Centro CNR di Studio per la Elettrochimica e la Chimica Fisica delle Interfasi, Rome, Italy

Received 4 October 2000; received in revised form 20 December 2000; accepted 26 January 2001

\begin{abstract}
Platinum electrodes modified with a cellulose acetate membrane or with poly(1,8-diaminonaphthalene) film were assembled and used for rapid amperometric detection of nitrites and nitrates in water by batch and flow injection analysis.

Parameters such as the permeability of the electropolymerised films to nitrites and nitrates, interference effects and recovery studies of these kinds of sensors have been optimised to demonstrate the analytical suitability of the proposed method.

Contrary to the standard colorimetric method, which is based on carcinogenic reagents, the amperometric detection of nitrites and nitrates is very simple and rapid and does not require any reagent for nitrite detection. Also, this method could be extended easily to the analysis of nitrites and nitrates in various types of samples such as food, soils, vegetables and fertilisers. (C) 2001 Elsevier Science B.V. All rights reserved.
\end{abstract}

Keywords: Non-conducting polymers; Electropolymerisation; Amperometric sensors; Flow injection analysis; Nitrites and nitrates detection

\section{Introduction}

The quantitative determination of nitrite and nitrate concentration is of rapidly increasing interest, especially for drinking water quality, wastewater treatment, for the food industry and for the control of remediation procedures. Also, the control of water quality is important to avoid contamination of food produced when water is used as a raw material.

Moreover, nitrates and nitrites are routinely added to meat products as a preservative against food poisoning microorganisms such as Clostridium botulinum [1]. Both nitrites and nitrates are also continuously monitored because of their toxicity. Nitrites can be converted to carcinogenic nitrosoamines in food products and within the human digestive system [2]. Nitrates, although more stable and less toxic than nitrites, are also a concern because they can be readily converted to nitrites by microbial reduction in food products $[3,4]$.

* Corresponding author. Tel.: + 39-6-497-66743/70; fax: + 39-6497-66749.

E-mail address: antonella.curulli@uniromal.it (A. Curulli).
There are many published methods for the determination of nitrites and nitrates, based on spectrophotometry, ion chromatography, chemiluminescence and electrochemistry, but none of them is considered satisfactory [5-9]

Nitrites are traditionally determined spectrophotometrically by their reaction with sulphanilamide and $N$-1-naphthylenediamine [5]. This method requires careful control of acidity for each step of the process and it has carcinogenic effects and can be unreliable due to the interferences present in the sample matrix from the strong oxidants and coloured substances. Nitrates were generally reduced to nitrites on a copperised cadmium column and then determined spectrophotometrically by the previous (Griess) reaction. However, this methodology requires several steps of sample pretreatment.

In the last 20 years, numerous IC and HPLC methods have been developed that are faster, more accurate and more sensitive than spectrophotometric methods [6-8]. However, these methods are often time consuming and require sample pre-treatment. 
Nitrites are an electroactive species readily oxidised at platinum electrodes polarised at $+0.9 \mathrm{~V}$ vs silver silver chloride [10]. Since the potential for nitrite oxidation is high, many other electroactive compounds present in complex media can interfere in the nitrite analysis. In order to avoid these interferences several other electrochemical procedures have been reported in the literature [11-15]. Among the electrochemical procedures for nitrate and/or nitrite detection, there are direct cathodic reduction at $\mathrm{Cu}$ and $\mathrm{Cd}$ electrodes [11]; measurement of the catalytic current observed for the polarographic reduction of transition metals as $\mathrm{Mo}(\mathrm{VI})$ in the presence of nitrite or nitrate [13]; electroactivity of nitrites/nitrates at chemically modified electrodes [14]; and chemical reaction between the analyte and a reagent selected so that a product of the reaction can be monitored easily with an electrode [15].

Besides the standard spectrophotometric methods [5], enzyme electrodes could be an alternative for determination of nitrites/nitrates [16]. Nitrite reductase enzymes have been coupled with an amperometric redox electrode for the detection of nitrites [16]: the drawback of this kind of biosensor is related to the stability of the enzyme under operative conditions.

In this paper, a new electrochemical procedure for nitrite and nitrate determination based on direct nitrite oxidation in an acetate buffer at a platinum electrode polarised at $+0.9 \mathrm{~V}$ vs an $\mathrm{Ag} \mid \mathrm{AgCl}$ reference electrode is proposed. In order to exclude the most common electrochemical interferences, the electrodes were covered with a cellulose acetate membrane or with a selected electropolymerised film. The new nitrite sensors were fully characterised in batch and flow injection analysis (FIA) and applied for nitrite and nitrate determination in drinking waters.

\section{Experimental}

\subsection{Reagents and solutions}

1,2-Diaminobenzene (1,2-DAB), 1,3-diaminobenzene (1,3-DAB), 1,5-diaminonaphthalene (1,5-DAN), 1,8-diaminonaphthalene (1,8-DAN), 5-amino-1-naphthol $(5 \mathrm{~A} 1 \mathrm{~N})$ and $o$-anisidine were from Fluka, Buchs, Switzerland. Ascorbic acid (AA), potassium nitrite, potassium nitrate and all other reagents of analytical grade were from Sigma Chemical Co., St. Louis, MO.

Phosphate buffers $\left(0.1 \mathrm{~mol}^{-1}\right)$ were prepared with distilled-deionized water using sodium dihydrogen phosphate dihydrate (Fluka Biochemical Microselect for molecular biology). For $\mathrm{pH}$ adjustments, pellets of sodium hydroxide were used.

Acetate buffer solution was prepared from 0.1 mol $1^{-1}$ sodium acetate and the $\mathrm{pH}$ was adjusted to 4.0 with acetic acid. All solutions were prepared with bidistilled water.

\subsection{Apparatus}

An AMEL polarographic system Model 433A (AMEL, Milan, Italy) was used for the voltammetric studies. The amperometric measurements were carried out with an $\mathrm{ABD}$, amperometric biosensor detector (Universal Sensor Inc., Metaire, LA). Currents were recorded using a Linseis L6512 recorder (Linseis, Selb, Germany). For batch measurements a platinum (Pt) working electrode (1.6 mm diameter) (Model MF2013) from BAS, Bioanalytical System (Lafayette, IN) and a combined auxiliary/reference electrode (Pt$\mathrm{Ag}|\mathrm{AgCl}| 3 \mathrm{M} \mathrm{KCl}$ ) (Model 805/CPG/6) from AMEL (Milan, Italy) were used.

For FIA we used a wall-jet cell (Model 656) from Metrohm, Herisau, Switzerland, assembled with the same platinum working electrode as was used for the batch analysis. The peristaltic pump Minipuls 3 (Gilson, France) and a six-way injection valve (Model 5020) with a closed loop of $250 \mu$ l (Rheodyne, USA) were used. The PTFE connection tubes (i.d. $0.5 \mathrm{~mm}$ ) were from Supelco (Bellofonte, CA); the T-connector valves and a chromatography column $(50 \mathrm{~mm}$ complete length and $0.35 \mathrm{ml}$ bed volume) equipped with frits (PTFE pore size $100 \mu \mathrm{m}$ ) were from Omnifit, (New Jersey).

\subsection{Procedure}

\subsubsection{Electrode polishing}

The platinum electrode surfaces were polished with alumina powder $\left(\mathrm{Al}_{2} \mathrm{O}_{3}\right.$, Buehler, Evanston, IL) of particle sizes of $1,0.3$, and $0.05 \mu \mathrm{m}$ before use. After careful rinsing with distilled water, the electrodes were pre-treated by potential cycling in $0.5 \mathrm{~mol}^{-1} \mathrm{H}_{2} \mathrm{SO}_{4}$ from -0.2 to $+1.2 \mathrm{~V}$ (vs SCE) at a scan rate of 20 $\mathrm{mV} \mathrm{s}^{-1}$, until no changes were observed in the cyclic voltammograms [17].

\subsubsection{Electropolymerisation}

1,2-DAB, 1,3-DAB, 1,5-DAN, 1,8-DAN, 5A1N and $o$-anisidine were electropolymerised on the electrode by cyclic voltammetry. All the monomers except the diaminonaphthalene isomers were used at a concentration of $5 \times 10^{-3} \mathrm{~mol} \mathrm{l}^{-1}$ and dissolved in $0.1 \mathrm{moll}^{-1}$ phosphate buffer solution at $\mathrm{pH} 6.5$ [18]. The substituted naphthalene derivatives $\left(5 \times 10^{-3} \mathrm{moll}^{-1}\right)$ were electropolymerised in $0.2 \mathrm{moll}^{-1} \mathrm{NaCl}$ and balanced to $\mathrm{pH} 1.0$ with concentrated $\mathrm{HCl}$ [19]. This greater acidity was required for solubilization of the substituted naphthalenes, presumably because of their higher hydrophobicity.

The potential was continuously cycled from 0 to $+0.8 \mathrm{~V}$ for $1,2-\mathrm{DAB}$, and from -0.15 to $+1.30 \mathrm{~V}$ for the naphthalene derivatives. The scan rate was 2 $\mathrm{mV} \mathrm{s}^{-1}$, and the potential was continuously cycled 
until a minimum value of current, which remained constant after further cycling, was observed.

Some of the coated electrodes were tested on subsequent days for response vs nitrites and interferences. The electrodes were stored in $\mathrm{pH}$ 7.4 PBS at $4^{\circ} \mathrm{C}$ when not in use.

\subsubsection{Preparation of home-made cellulose acetate membranes}

Cellulose acetate membranes were prepared by dissolving $2 \mathrm{~g}$ of cellulose acetate $(53 \%)$ and $20 \mathrm{mg}$ of polyvinyl acetate (Carlo Erba, Milan, Italy) in $30 \mathrm{ml}$ acetone and $20 \mathrm{ml}$ cyclohexanone. For casting the cellulose membrane, a precision gauge tool (from Precision Gage and Tool Co., Dayton, $\mathrm{OH}$ ) was used.

\subsubsection{Copperised cadmium column preparation}

For nitrate determination we used copperised cadmium granules, which reduce nitrates to nitrites quantitatively. The steps for the reduction column preparation are those reported in the standard methods of nitrate analysis in water [5]:

1. washing with acetone (3-4 times) for degreasing 3.5 g cadmium granules (Aldrich, 30-80 mesh);

2. swirling the granules in $20 \mathrm{ml} 2 \mathrm{M} \mathrm{HCl}(10 \mathrm{~min})$;

3 . washing the granules with distilled water till the $\mathrm{pH}$ of the washing water is above 5;

4. treating the cadmium granules with $20 \mathrm{ml} 2 \%$ $\mathrm{CuSO}_{4}$ until the blue colour disappears and a brown colloidal precipitate begins to develop;

5. decanting the supernatant and washing the copperised cadmium granules with distilled water $(10$ 15 times) till all the brown precipitate is removed;

6. suspending the granules in $0.625 \% \mathrm{NH}_{4} \mathrm{Cl}$ solution and packing into the chromatographic column.

This quantity of cadmium granules $(3.5 \mathrm{~g})$ is sufficient to fill two columns with the dimensions reported above. Before use, the column was washed with $150 \mathrm{ml}$ of distilled water. After use, the column was washed with $50 \mathrm{mM} \mathrm{NH} \mathrm{NH}_{4} \mathrm{Cl}$ and stored in a refrigerator.

\subsubsection{Batch procedure}

The nitrite sensor polarised at $+0.9 \mathrm{~V}$ was immersed in $10 \mathrm{ml}$ of stirred acetate buffer solution $(0.1$ mol $\left.1^{-1}, \mathrm{pH} 4.0\right)$ and then allowed to equilibrate. Aliquots of standard nitrite solutions were then injected into the buffer and the current changes were recorded.

\subsubsection{FIA procedure}

A FIA manifold is shown in Fig. 1. A $250 \mu$ closed loop of the six-way injection valve previously connected in series to the flow system was filled with the analysing solution. By switching the six-way valve to the inject position, the solution was injected into the flow stream and a transient current variation due to nitrite oxidation was recorded. The copperised cadmium column was inserted between the pump and the six-way valve. The sample can then flow through the column for nitrate determination or bypass it for nitrite determination.

Prior to any measurement, a concentrated ammonium chloride solution $\left(0.5 \mathrm{moll}^{-1}\right)$ was added to the standards or samples to obtain a final concentration of $50 \mathrm{mmol} \mathrm{l}^{-1}$.

The acquisition of each datum was performed at least three times; the results were then averaged. The detection limit was defined as a signal-to-noise ratio of 3.

\subsubsection{Spectrophotometric procedure}

Nitrites were determined spectrophotometrically by their reaction with sulphanilamide and $N$-1-naphthylenediamine. Nitrates were reduced to nitrite on the copperised cadmium column and determined spectrophotometrically by the previous (Griess) reaction.

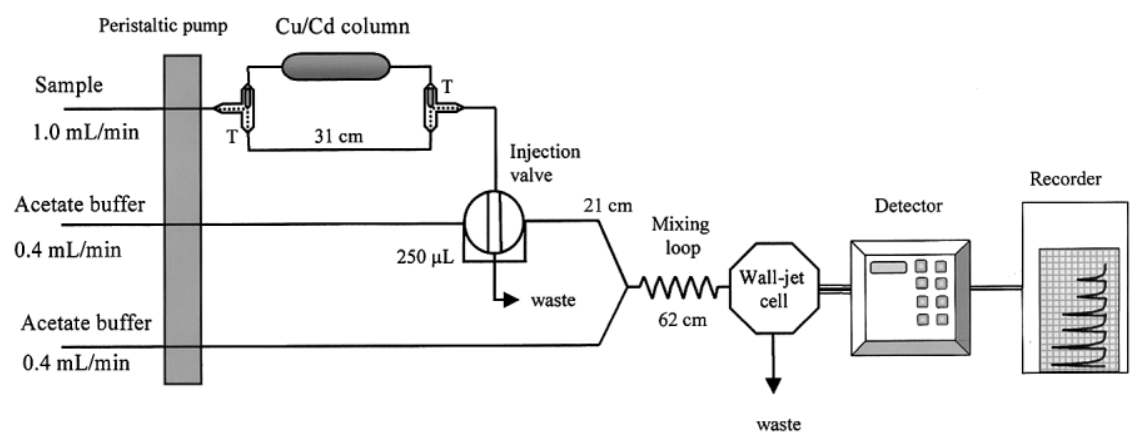

Fig. 1. Proposed manifold for the determination of nitrites and nitrates. 
Table 1

Permeability of various electropolymerised films to nitrite and to ascorbic acid

\begin{tabular}{lclc}
\hline $\begin{array}{l}\text { Monomers used for the } \\
\text { formation of } \\
\text { electropolymerised films }\end{array}$ & $P_{1} / \%{ }^{\mathrm{a}}$ & $P_{2} / \% \mathrm{~b}$ & $P_{1} / P_{2}{ }^{\mathrm{c}}$ \\
\hline 1,2-DAB & 3.8 & 0.15 & \\
1,3-DAB & 6.3 & 0.18 & 35 \\
5A1N & 44 & 0.6 & 73 \\
$o$-Anisidine & 62 & 1.2 & 52 \\
1,5-DAN & 24 & 0.8 & 30 \\
1,8-DAN & 35 & 0.3 & 117 \\
\hline
\end{tabular}

a Permeability of the film to nitrites.

${ }^{\mathrm{b}}$ Permeability of the film to ascorbic acid.

${ }^{\mathrm{c}}$ Permselectivity.

\section{Results and discussion}

\subsection{Batch analysis}

\subsubsection{Nitrite sensor based on cellulose acetate mem- brane}

Since the potential of nitrite oxidation is high, many other electroactive species present in complex media can be oxidised and thus interfere with the nitrite analysis. In order to avoid these interferences we covered the electrode surface with a cellulose acetate (CA) membrane. This membrane, which is about 100 $\mathrm{g} \mathrm{mol}^{-1} \mathrm{MMCO}$ (molar mass cut off), was prepared as previously reported [20-22] and was used to assemble biosensors to study such complex matrices as whole blood or foods. The membrane is negatively charged and protects the electrode from protein adsorption and from interfering species such as ascorbic and uric acid.

The CA membrane was used for the construction of amperometric biosensors as a selective membrane for hydrogen peroxide but never tested for its permeability to nitrites. In this case, the permeability $(P)$ was defined as follows:

$P=\left(I_{\text {membrane }} / I_{\text {bare }}\right) \times 100 \%$

where $I_{\text {bare }}$ refers to the current measured at the naked electrode and $I_{\text {membrane }}$ refers to the current measured at the electrode covered with the CA membrane. Ascorbic acid was used as a model molecule to test the permselectivity of the CA membrane. The results showed that the permeability of the CA membrane to $0.1 \mathrm{mmol}^{-1}$ nitrites and $0.1 \mathrm{mmol} 1^{-1} \mathrm{AA}$ was 7 and $0 \%$, respectively. It should be noted that a slow response of AA could be observed after a few minutes due to the slight diffusion of AA through the CA membrane. Using the CA membrane, a good linearity was observed over the whole range studied $(1-100$ $\mu \mathrm{mol} 1^{-1}$ nitrites). The equation was $I=-0.010+$ $0.140 x, r=0.999$, where $I$ was the current in $\mathrm{nA} ; x$ was the concentration in $\mu \mathrm{mol} 1^{-1}$ and $r$ was the correlation coefficient. The detection limit was $0.5 \mu \mathrm{mol} 1^{-1}$.
The CA membrane is mechanically stable and was used for more than three months without any loss of permselectivity.

\subsubsection{Nitrite sensor based on electropolymerised films}

Although the CA membrane showed good stability and a long lifetime, it did not exhibit a high sensitivity towards nitrites. For this reason various electropolymerised films were prepared and tested for their permselectivity to nitrites. The permeability of the film to nitrites and to AA is defined for CA, where $I_{\text {membrane }}$ was replaced by $I_{\text {film }}$. From the results reported in Table 1 it is clear that all the electropolymerised films reduce the AA interference. However, the best permselectivity, defined as permeability(nitrite)/permeability(AA), which gave a high response to nitrite and a low response to AA, was obtained with poly(1,8DAN). Thus, its monomer was selected for further experiments. It should be noted that it is impossible to predict with accuracy the permeability of these polymeric films from their proposed structures [19]. It is known that the experimental conditions of the electropolymerisation influence the permselectivity of the film $[18,23]$. The variation in the permeabilities of the various films could be explained by their degree of hydrophobicity.

Considering poly(1,2-DAB), poly $(o$-anisidine $)$ and poly(1,3-DAB), only one amino or hydroxyl group is involved in the polymer formation and the monomers are relatively hydrophilic. Consequently, there will be a low degree of cross-linking between the polymer chains with, at least, a comparable [see poly $(o$-anisidine $)$ ] or lower [see poly(1,2-DAB) and poly(1,3-DAB)] permselectivity with respect to the poly(substituted naphthalenes).

The poly(substituted naphthalene) films are more hydrophobic and a lower degree of solvation, a closer packing of the polymer chains and a lower permeability vs AA are observed (see Ref. [19]).

It is difficult to explain the different permselectivities among the poly(substituted naphthalenes), but as shown in Table 1, the best permselectivity can be considered as a compromise between a good permeability vs nitrite and a good rejection vs AA.

On the other hand, the stability of the response vs AA and nitrites of different films with time is another parameter that has been considered.

According to the permselectivity data reported in Table 1 , poly $(5 \mathrm{~A} 1 \mathrm{~N})$, poly $(o$-anisidine $)$ and $\operatorname{poly}(1,8-$ DAN) showed the higher $P_{1} / P_{2}$, but after $48 \mathrm{~h}$ such a ratio remained constant only for poly $(1,8-\mathrm{DAN})$. The other two films showed a $P_{1} / P_{2}$ decrease of 30 and $40 \%$, respectively. Further studies are in progress to explain such a decrease, by means of a comparative analysis of the film structure. 
Table 2

Influence of the reduction medium on the conversion yield of the nitrates to nitrites; flow rate through the $\mathrm{Cu} / \mathrm{Cd}$ column $=1 \mathrm{ml} \mathrm{min}{ }^{-1}$

\begin{tabular}{|c|c|c|}
\hline \multirow[t]{2}{*}{ Reduction medium } & \multicolumn{2}{|c|}{ Conversion yield $/ \%$} \\
\hline & $\begin{array}{l}{[\text { Nitrates }]=50} \\
\mu \mathrm{mol} 1^{-1}\end{array}$ & $\begin{array}{l}{[\text { Nitrates }]=500} \\
\mu \mathrm{mol} 1^{-1}\end{array}$ \\
\hline $50 \mathrm{mmol} \mathrm{l}^{-1} \mathrm{NH}_{4} \mathrm{Cl}$ & 100 & 100 \\
\hline $\begin{array}{l}\text { Ammonium chloride buffer, } \\
50 \mathrm{mmol}^{-1}, \mathrm{pH} 9.0\end{array}$ & 100 & 100 \\
\hline $\begin{array}{l}\text { Ammonium acetate buffer } 50 \\
\mathrm{mmol}^{-1}, \mathrm{pH} 9.0\end{array}$ & 57 & 50 \\
\hline $\begin{array}{l}\text { Sodium acetate buffer } 0.1 \\
\text { mol } 1^{-1}, \mathrm{pH} 4.0\end{array}$ & 17 & 15 \\
\hline
\end{tabular}

Under our experimental conditions the best permselectivity was obtained with poly(1,8-DAN) and thus it was selected for further tests.

Using the poly(1,8-DAN), a good linearity was obtained over the whole range studied $(0.5-100$ $\left.\mu \mathrm{mol}^{-1}\right)$. The equation was $I=0.067+0.700 x, r=$ 0.999 , where $I$ was the current in $\mathrm{nA} ; x$ the concentration in $\mu \mathrm{mol}^{-1}$ and $r$ the correlation coefficient. The detection limit was $0.1 \mu \mathrm{moll}^{-1}$.

The nitrite sensor based on poly(1,8-DAN) was five times more sensitive than that based on a CA membrane. This sensor needed about one night of stabilisation in $\mathrm{pH} 4$ acetate buffer at $+0.9 \mathrm{~V}$ before the first use and maintained a stable response for at least four months (a longer time has not been tested). The sensor was stored in $\mathrm{pH} 7.4 \mathrm{PBS}$ at $4^{\circ} \mathrm{C}$ when not in use.

The response time in batch analysis, using $3 \times 10^{-3}$ mol $1^{-1}$ of nitrites $(95 \%$ of steady state current), was $10 \mathrm{~s}$ for the $\mathrm{Pt} /$ poly $(1,8-\mathrm{DAN})$ probe and $45 \mathrm{~s}$ for the $\mathrm{Pt} / \mathrm{CA}$ probe.

\subsection{Flow injection analysis}

Fig. 1 shows the proposed manifold for the determination of nitrates and nitrites, where the sample continuously fills the mixing loop. Nitrate is reduced to nitrite by passing it through a copperised cadmium column. The resulting nitrite plus any nitrite originally present in the sample is determined as a sum by the nitrite oxidation at the probe. The endogenous nitrite alone can be determined by bypassing the cadmium column. Therefore, the nitrate is calculated by the difference.

The optimum values for the flow rate and for the loop volume were obtained by injection of $10 \mu \mathrm{mol} 1^{-1}$ nitrites. The best compromise between throughput and sensitivity was obtained with a loop volume of $250 \mu 1$ and a flow rate of $0.8 \mathrm{ml}$.

The influence of the reduction medium on the conversion yield of the nitrate to nitrite was studied. Table 2 clearly shows that the sodium acetate buffer which is used in our manifold as a carrier cannot be used as a reduction medium since the conversion yield is low $(15 \%)$. From the literature $[24,25]$ we found that the ammonium buffer was used to increase the conversion yield. In our case we found that the unbuffered ammonium solution gives 100\% conversion yield. Further studies showed that changing the ammonium concentration from 25 to $100 \mathrm{moll}^{-1}$ and changing the flow rate from 1 to $2 \mathrm{ml} \mathrm{min}^{-1}$ did not affect the column efficiency. We selected, for further experiments, an ammonium solution of $50 \mathrm{mmol}^{-1}$ and a flow rate of 1 $\mathrm{ml} \mathrm{min}^{-1}$.

In order to study the influence of the nitrite/nitrate ratio on the current response, five different standard solutions were prepared. In each solution the concentration of nitrate plus nitrite was kept constant.

The results showed that the efficiency of the column was independent of the concentration of the nitrite originally present in the sample. Bypassing the $\mathrm{Cu} / \mathrm{Cd}$ column the signal response was proportional to the nitrite concentration and independent of the nitrate originally present in the sample.

For example, the results reported in Table 3, relative to a $\mathrm{Pt} / \operatorname{poly}(1,8-\mathrm{DAN})$ probe, showed that a solution of $100 \mu \mathrm{mol}^{-1}$ of nitrate plus nitrite, when passed through the cadmium column gave a signal from 34.6 to $35.6 \mathrm{nA}$ for all the ratios of nitrate and nitrite studied.

Table 3

Influence of nitrate/nitrite ratio on $\mathrm{Pt} / \mathrm{poly}(1.8-\mathrm{DAN})$ sensor response

\begin{tabular}{|c|c|c|c|c|}
\hline \multirow[t]{2}{*}[\mathrm{NO}_{2}^{-}]{$/ \mu \mathrm{mol} \mathrm{l}^{-1}$} & \multirow[t]{2}{*}{$\left.\mathrm{NO}_{3}^{-}\right] / \mu \mathrm{mol}^{-1}$} & \multirow[t]{2}{*}{ Nitrite/nitrate ratio } & \multicolumn{2}{|c|}{$I / \mathrm{nA}$ obtained for the standard } \\
\hline & & & Through $\mathrm{Cu} / \mathrm{Cd}$ column & Bypassing $\mathrm{Cu} / \mathrm{Cd}$ column \\
\hline 75 & 25 & $3: 1$ & 35.6 & 26.9 \\
\hline 50 & 50 & $1: 1$ & 35.3 & 18.8 \\
\hline 25 & 75 & $1: 3$ & 35 & 8.8 \\
\hline
\end{tabular}


Table 4

Recovery study performed adding standard solutions of nitrites to tap water samples. The nitrite sensor was a platinum electrode modified with CA membrane

\begin{tabular}{|c|c|c|c|c|c|}
\hline $\begin{array}{l}\text { Nitrites } \\
\text { added } / \mu \mathrm{mol} 1^{-1}\end{array}$ & $\begin{array}{l}\text { Nitrites found before } \\
\text { spiking } / \mu \mathrm{mol} 1^{-1}\end{array}$ & Expected value $/ \mu \mathrm{mol} 1^{-1}$ & $\begin{array}{l}\text { Measured } \\
\text { value } / \mu \mathrm{mol} 1^{-1}\end{array}$ & Recovery $/ \%$ & $\mathrm{RSD} / \%$ \\
\hline 5.0 & 0 & 5.0 & 4.8 & 96 & 0.8 \\
\hline 20.0 & 0 & 20.0 & 19.9 & 99 & 1.0 \\
\hline
\end{tabular}

Table 5

Recovery study performed by adding standard solutions of nitrates to mineral water samples. The nitrite sensor was a platinum electrode modified with poly(1,8-DAN) film

\begin{tabular}{|c|c|c|c|c|c|}
\hline $\begin{array}{l}\text { Nitrates } \\
\text { added } / \mu \mathrm{mol} 1^{-1}\end{array}$ & $\begin{array}{l}\text { Nitrates found in the sample } \\
\text { before spiking } / \mu \mathrm{mol} 1^{-1}\end{array}$ & Expected value $/ \mu \mathrm{mol} 1^{-1}$ & $\begin{array}{l}\text { Measured } \\
\text { value } / \mu \mathrm{mol} \mathrm{1} 1^{-1}\end{array}$ & Recovery $/ \%$ & $\mathrm{RSD} / \%$ \\
\hline 40.0 & 73.6 & 113.6 & 111.2 & 98 & 0.7 \\
\hline 200.0 & 73.6 & 273.6 & 262.5 & 96 & 0.8 \\
\hline
\end{tabular}

Since the $\mathrm{Cu} / \mathrm{Cd}$ column showed an efficiency of $100 \%$ and since the response of nitrite was not affected by the presence of nitrates, one calibration curve using nitrite or nitrate standards was performed. In our preliminary experiments, a different arrangement of the manifold shown in Fig. 1 was used: the $\mathrm{Cu} / \mathrm{Cd}$ column and the $\mathrm{T}$-valves were placed between the injection valve and the wall-jet cell. In this way the standard solution was aspirated from the pump to the injection valve, then passed through the column for nitrate determination, or bypassed the column for nitrite determination. In this case we found that the slope of the nitrate curve was lower than the slope of the nitrite curve due to the dispersion of the standard nitrate in the column. Since two calibration curves were necessary this manifold was modified and the flow injection system designed in Fig. 1 was used. With this FIA system the sensitivity of the calibration curves was lower than the values reported for the batch analysis. The detection limits were $1 \mu \mathrm{mol}^{-1}$ for the nitrite sensor based on a CA membrane and $0.25 \mu \mathrm{mol}^{-1}$ for that assembled with poly(1,8-DAN), respectively.

The use of a mixing coil, $62 \mathrm{~cm}$ long, showed better precision. Indeed, 10 consecutive analyses of standard nitrites $\left(10 \mu \mathrm{mol}^{-1}\right)$ gave a relative standard deviation (RSD) of around $0.7 \%$. Similarly, 10 consecutive analyses of nitrate standard solution $\left(10 \mu \mathrm{mol}^{-1}\right)$ gave an RSD of around $0.8 \%$, which indicates a better reproducibility. The throughput was around 15 determinations of nitrates plus nitrites per hour.

\subsection{Water analysis}

\subsubsection{Interference study}

The effects of co-existing species in drinking water on nitrite determination using flow injection analysis were assessed by comparing the response of $10 \mu \mathrm{moll}^{-1}$ of nitrites and $10 \mu \mathrm{mol}^{-1}$ of nitrites in the presence of the most common co-existing species at their maximum admissible concentrations [26]. The results showed that the presence of $\mathrm{Cl}^{-}, \mathrm{SO}_{4}^{2-}, \mathrm{Ca}^{2+}, \mathrm{Mg}^{2+}, \mathrm{Na}^{+}, \mathrm{K}^{+}$, $\mathrm{Al}^{3+}, \mathrm{CO}_{3}^{-}, \mathrm{Mn}^{2+}, \mathrm{Cu}^{2+}, \mathrm{Zn}^{2+}, \mathrm{PO}_{4}^{3-}$ did not affect the nitrite determination.

\subsubsection{Recovery}

Nitrite and nitrate recovery data were obtained with both sensors.

Standard solutions of nitrites were added to a tap water sample (where nitrite was absent) to obtain a final concentration of 5, 10 and $20 \mu \mathrm{mol}^{-1}$. Standard solutions of nitrates were added to a mineral water (containing $73.6 \mu \mathrm{mol}^{-1}$ of nitrates) to obtain a final concentration of $113.6,173.6$ and $273.6 \mu \mathrm{mol}^{-1}$. The recovery (average of three determinations) and precision data are reported in Tables 4 and 5. The nitrite sensors based on the CA membrane and the poly $(1,8$ DAN) film both gave a recovery from 95 to $100 \%$ and a RSD less than $1 \%$.

\subsubsection{Method of comparison}

The continuous flow determinations with nitrite sensors based on cellulose acetate membrane and poly $(1,8-$ DAN) film were compared with the standard colorimetric method [5].

The proposed method and the colorimetric method were applied to the tap water and mineral water samples. Nitrites were under the detection limit of all the methods. The nitrate values are reported in Tables 6 and 7 . The difference between the colorimetric and the proposed methods did not exceed $\pm 4 \%$. 
Table 6

Comparison between a standard colorimetric method and the proposed method based on flow injection analysis and a platinum electrode covered with cellulose acetate membrane for nitrate determinations

\begin{tabular}{lccc}
\hline Samples & $(B)$ Proposed method $/ \mathrm{mg} 1^{-1}$ & $(A)$ Colorimetric method $/ \mathrm{mg}^{-1}$ & $(A-B / A) / \%$ \\
\hline Tap water & 14.7 & 14.4 & -2 \\
Mineral water Capannelle 1 & 40.0 & 41.3 & +3 \\
Mineral water Ferrarelle 1 & 4.8 & 4.9 & +2
\end{tabular}

Table 7

Comparison between a standard colorimetric method and the proposed method based on flow injection analysis and a platinum electrode covered with poly(1,8-DAN) film for nitrate determinations

\begin{tabular}{llrl}
\hline Samples & $(B)$ Proposed method $/ \mathrm{mg} 1^{-1}$ & $(A)$ Colorimetric method $/ \mathrm{mg} 1^{-1}$ & $(A-B / A) / \%$ \\
\hline Tap water & 22 & 21.8 & -1 \\
Mineral water Capannelle 2 & 44 & 44.9 & +2 \\
Mineral water Ferrarelle 2 & 4.9 & 5.1 & +4 \\
\hline
\end{tabular}

\section{Conclusions}

Platinum electrodes modified with cellulose acetate membrane or poly(1,8-DAN) film appeared to be useful sensors for nitrite determination. Moreover, it was shown that these sensors had good potential for rapid detection of nitrites and nitrates in water.

Contrary to standard colorimetric methods, which are based on carcinogenic reagents, the proposed procedure was very simple and rapid and did not require any reagent for nitrite detection.

\section{Acknowledgements}

The authors wish to acknowledge the CNR-Italy and CNCPRST-Morocco and the European Community (ERBIC Project no.15 CT 980119) for financial support.

\section{References}

[1] P.F. Swann, Proc. R. Soc. Med. 70 (1977) 113.

[2] C.L. Walters, Oncology 37 (1980) 289.

[3] M.J. Dennis, P.E. Key, T. Papworth, Food Additive Contam. 7 (1990) 455.

[4] R.G. Cassens, Food Technol. (1995) 72.
[5] Standard Methods for the Examination of Water and Waste Water, American Public Health Association, New York, 1995.

[6] B. Schmidt, G. Schwedt, Dtsch. Lebensm. Rundsch. 80 (1984) 137.

[7] E. Bianchi, R. Bruschi, R. Draisci, L. Lucentini, Z. Lebensum, Unters. Forsch. 200 (1995) 256.

[8] H.J. Kim, K.R. Conca, J. Assoc. Off. Anal. Chem. 73 (1990) 561.

[9] M. Bertotti, D. Pletcher, Anal. Chim. Acta 337 (1997) 49.

[10] R. Guidelli, F. Pergola, G. Raspi, Anal. Chem. 44 (1972) 745.

[11] N.G. Carpenter, D. Pletcher, Anal. Chim. Acta 317 (1995) 287.

[12] A.Y. Camsi, A.G. Fogg, Analyst 113 (1988) 81.

[13] A. Schultz, J. Electroanal. Chem. 237 (1984) 163.

[14] A.P. Doherty, J.G. Vos, J. Chem. Soc. Faraday Trans. 88 (1992) 2903.

[15] M. Trojanowicz, Anal. Chim. Acta 261 (1992) 391.

[16] L.M. Moretto, P. Ugo, M. Zanata, P. Guerriero, C.R. Martin, Anal. Chem. 70 (1998) 2163.

[17] A. Capon, R. Parsons, J. Electroanal. Chem. 65 (1975) 285.

[18] A. Curulli, G. Palleschi, Electroanalysis 9 (1997) 1107 (and references therein).

[19] L.J. Murphy, Anal. Chem. 70 (1998) 2928.

[20] M. Mascini, F. Mazzei, Anal. Chim. Acta 9 (1987) 192.

[21] P.J. Taylor, E. Kmetec, J.M. Johnson, Anal. Chem. 49 (1977) 789.

[22] G. Palleschi, M.A. Nabi Rahni, G.J. Lubrano, J.N. Ngwainbi, G.G. Guilbault, Anal. Biochem. 159 (1986) 114.

[23] S.A. Emr, A.M. Yacynych, Electroanalysis 7 (1995) 913.

[24] F. Nydahl, Talanta 23 (1976) 346.

[25] J. Halasz, G. Horvai, Electroanalysis 4 (1992) 469.

[26] Official Journal of European Union 15 July 1980 (80/778/EU). 